Forthcoming in Journal of Common Market Studies

\title{
Distributive Politics, Electoral Institutions, and European Structural and Investment Funding: Evidence from Italy and France
}

\author{
Lisa M. Dellmuth*, Dominik Schraff, and Michael F. Stoffel
}

\begin{abstract}
Extensive research suggests that political factors bias the domestic allocation of the European Union (EU) Structural and Investment Funds (SIF) in ways that may not be in line with EU goals. This paper offers the first systematic and comparative analysis of the role of domestic electoral institutions in shaping politicians' incentives to use European funds to buy votes. Drawing on theories of distributive politics and SIF implementation, the paper argues that electoral institutions provide politicians with incentives to use at least a part of the SIF to buy votes, and that the vote-seeking behavior of national governments is relatively unconstrained by the bargaining power of the European Commission or regions. The empirical results from a statistical analysis of SIF allocations within Italian and French NUTS3-level regions endorse the argument, with implications for the effectiveness of the SIF in promoting sustainable and inclusive development in European regions.

\section{Acknowledgements}

Earlier versions of this article were presented at the 8th Annual Conference on the Political Economy of International Organizations in Berlin 2014 and the ECPR Annual Conference in Glasgow 2014. We want to express warm thanks to Daniele Caramani and the three anonymous reviewers for helpful comments and suggestions. Lisa Dellmuth wishes to acknowledge the funding of the Early Career Grant by the Regional Studies Association.
\end{abstract}

*Corresponding author: Stockholm University, Department of Political Science, SE-10691 Stockholm. Email: lisa.dellmuth@statsvet.su.se. 


\section{Introduction}

In the past three decades, European Union (EU) cohesion policy and its Structural and Investment Funds (SIF) have increasingly been used to promote economic and social cohesion among European (subnational) regions. Introduced in 1975 with modest resources, the SIF are nowadays considered to be key delivery mechanisms for achieving the 'Europe $2020^{\prime}$ goals of sustainable and inclusive growth. The SIF are designed to make European regions more competitive, while lifting 20 million people out of social exclusion and poverty (European Communities, 2007; European Commission, 2010). The increasing financial volume and importance of the SIF for the European economy raise important questions about how far domestic governments distribute the SIF in line with EU goals. Despite growing scholarly interest in the political determinants of EU budgetary allocations across European regions (e.g., Kemmerling and Bodenstein, 2006; Bouvet and Dall'erba, 2010; Bodenstein and Kemmerling, 2011; Dellmuth, 2011; Chalmers, 2013), however, we still know little about the sources of actual cash flows through the SIF within recipient regions (cf. De Rynck and McAleavey, 2001; Dellmuth and Stoffel, 2012; Schraff, 2014).

This article seeks to fill this gap in the existing literature by exploring how and why electoral institutions influence the actual distribution of SIF within regions, that is, across counties. ${ }^{1}$ We conceptualize the county-level spending of SIF as an instance of national intergovernmental grants, jointly decided by the European Commission and the executive branches of regional and national government. In doing so, this article makes two principal contributions to the debate on EU budgetary implementation and cohesion policy.

\footnotetext{
${ }^{1}$ Following the European Commission's Nomenclature of territorial units for statistics (NUTS), we distinguish between the county, regional, and national level. We refer to counties as NUTS 3-level jurisdictions with 150800 thousand inhabitants. By regions we mean jurisdictions at the NUTS 2 level having a population of 0.8-3 million inhabitants or jurisdictions at the NUTS 1 level with a population of 3-7 million inhabitants (Regulation (EC) No. 1059/2003, available at: «http://eur-lex.europa.eu/legal-content/EN/TXT/PDF/?uri=CELEX:32003R1059\&from=EN»).
} 
First, we advance a specific argument about the conditions under which national executive governments have incentives to spend the SIF in ways that increase their re-election chances. Drawing from previous research on distributive politics in the domestic context (e.g., Bertelli and Grose, 2009; Berry et al., 2010; Kriner and Reeves, 2015), we argue that electoral institutions in unitary states provide national executives with incentives to secure the electoral benefits of EU funding. Following in the steps of the political economy of federalism (e.g., Riker, 1964; Campbell, 1986; Grossman, 1994; Solé-Ollé and Sorribas-Navarro, 2008), we expect the targeted spending of the SIF to be constrained by partisan harmony between regional and national executives that are jointly responsible for the distribution of SIF across counties. Furthermore, we take cues from previous literature on electoral rules and distributive politics (e.g., Persson and Tabellini, 2002; Kemmerling and Stephan, 2015) in developing our expectation that targeted spending should be more pronounced under majority voting (MAV) than in proportional representation voting (PRV) systems.

Second, we test the observable implications of our argument by using new SIF spending data from the most recent EU budgetary period (2007-2013), complemented with political and economic data for 202 counties in Italy and France. The choice of Italy and France was informed by two considerations. To begin with, we would ideally want to test our argument using data from countries in which the institutional features of the electoral system vary substantially. Our case selection enables us to do this, as France relies on two-round MAV whereas Italy has a PRV system. Moreover, this selection increases the external validity of our findings given the variability in regional authority in SIF management in unitary EU member states. In this respect, France is a unitary and centralized state while Italy is unitary and decentralized (cf. Chalmers, 2013; European Commission, 2015). Our data set enables a comparative analysis of the political and economic determinants of cash flows to counties, but also offers a unique resource for future research on SIF implementation and allocation. A 
series of statistical analyses suggest that county-level allocations of SIF in Italy and France are a function of national electoral institutions. Moreover, the political targeting of the SIF is more pronounced under MAV than under PRV. By contrast, we do not find that targeted spending is constrained in times of partisan alignment between regional and national executives.

These results advance on previous research in mainly three ways. First, our county-level analysis reflects vote-buying patterns more accurately than previous studies that have focused on the determinants of SIF allocations across more aggregated NUTS 1 or 2 regions. ${ }^{2}$ Second, in contrast to the existing literature on SIF appropriations across NUTS 1 and 2 regions (e.g., Kemmerling and Bodenstein, 2006; Bouvet and Dall'erba, 2010; Bodenstein and Kemmerling, 2011; Dellmuth, 2011; Chalmers, 2013), we examine actual cash flows. This is a central contribution since budgetary commitments to regions and actual payments in regions may vary considerably (Dellmuth, 2011). Third, while existing contributions on county-level SIF allocations are single-country studies (Dellmuth and Stoffel, 2012; Schraff, 2014), our comparative cross-national design enables us to analyze, for the first time, the roles of political institutions in shaping the distribution of SIF across counties. We conclude our article by discussing the findings and their implications for future research on EU budgetary implementation and cohesion policy.

\section{The Regional Allocation of EU Structural Funds}

The SIF are allocated in the form of matching grants to regions under the auspices of mainly two funding schemes: the European Regional Development Fund (ERDF) and the European Social Fund (ESF). Every seven years, the EU passes a seven-year budgetary plan ('financial perspective') that sets expenditure ceilings and eligibility criteria for the SIF. During the

\footnotetext{
${ }^{2}$ This assumption is warranted by the fact that 51 percent of the variation in the vote shares of all parties in national government occurs at the county (NUTS 3 ) level in Italy, and 35 percent in France, when comparing electoral outcomes at the regional (NUTS 2) and county (NUTS 3) level.
} 
period 2007-2013, 347 billion Euro were set aside to promote sustainable and equitable growth. While the ERDF targets mainly projects aiming to enhance growth through investment in small and medium enterprises, research and development, and transport infrastructure, the ESF prioritizes projects that promote employment, social inclusion, and education (European Communities, 2007; European Commission, 2010).

\section{The Negotiation Process}

The negotiation process culminating in the county-level allocation of SIF is in three parts. First, governments negotiate and decide in the European Council about the financial perspective that determines SIF appropriations across member states for a seven-year budgetary period. Second, regional and national governments as well as the Commission negotiate and jointly decide about SIF appropriations across regions. Third, regional and national executive governments share the responsibility for distributing the SIF in counties, whereby the Commission plays an advisory role. Given that we seek to explain variation in SIF allocations at the county level, we discuss the third stage of the negotiation process in greater detail below.

Once the SIF have been earmarked for regions, regional executive government at the NUTS 1 and 2 level and national executive government jointly manage the funds' distribution across counties (cf. Dellmuth and Stoffel, 2015; European Commission, 2015). The Commission assists regional and national policy-makers in formulating investment plans that include county-level spending priorities in NUTS 1 and 2 regions (cf. Bachtler and Méndez, 2007). Typically, there are two such plans for a country, one for ERDF funding and one for ESF funding. Both of these plans are managed by national governments. Furthermore, there are two plans in each NUTS 1 or 2 region, one for each fund. In Italy, investment plans (piano operativo regionale) are managed at the level of regioni, whereas in France, investment plans 
(programs opérationnels) are administered at the level of régions. For each investment plan, the Commission fixes an indicative amount of SIF for the seven-year period in a legally binding decision. In the course of the budgetary period, regional and national governments are responsible for reporting the financial implementation to the Commission. The Commission, in turn, is responsible for the correct implementation of the EU budget (cf. Dellmuth, 2011).

\section{Actor Discretion}

We conceive of discretion as the latitude of actors to choose procedures and distributive outcomes on the basis of formal European rules, minus the constraints placed upon these actors on the basis of formal rules (cf. Pollack, 2003: 28). When allocating SIF across counties, regional and national governments are limited by the boundaries set in the EU regulatory framework governing the SIF. This framework limits domestic actors' discretion in mainly two respects. First, the budget has to be implemented within the framework of 'shared management' between regional, national, and supranational actors (Articles 11 and 14 of Council regulation No 1083/2006). ${ }^{3}$ In this respect, member states have been granted more discretion during the budgetary period 2007-2013 in distributing the SIF across counties when compared to the period 2000-2006. At the same time, the Commission remains responsible for the formal approval of regional investment plans and for promoting EU goals through guidelines, aide-mémoires, and communications. Indeed, the Commission has intensified its efforts to exert 'soft influence' through guidelines during the period 2007-2013 to promote the 'Europe 2020' goals (Bachtler and Mendez, 2007, p. 554-5). Second, the EU regulatory framework specifies economic criteria for the allocation of SIF. At the beginning of the period 2007-2013, member states were transferred the responsibility to determine - during the second stage of the negotiation process - whether relatively rich NUTS 1 and 2 regions (so-

\footnotetext{
${ }^{3}$ Available at: «http://eur-lex.europa.eu/legal-content/EN/TXT/PDF/?uri=CELEX:32006R1083\&from=EN».
} 
called 'Regional Competitiveness and Employment' regions) were eligible to receive SIF. By contrast, the eligibility criteria for poorer NUTS 1 and 2 regions (so-called 'Convergence' regions) remained relatively fixed in the EU regulations (Bachtler and Mendez, 2007, p. 544). Domestic governments' discretion in selecting eligible NUTS 1 and 2 regions has implications for the amounts of funding received by NUTS 3 counties, but does not determine how much funding counties ultimately receive. The Commission does neither have the resources nor the incentives to dispute the political targeting of SIF (cf. Pollack, 2003; BlomHansen, 2005; Dellmuth and Stoffel, 2012). Taken together, domestic actors enjoy substantial discretion in distributing SIF across counties, increasing the likelihood that electoral considerations enter the allocation process.

\section{Theory: Electoral Institutions and the County-Level Allocation of SIF}

Extensive research shows that electoral institutions play an important role in shaping the attempts of politicians to secure the electoral benefits of national distributive awards (e.g., Cadot et al., 2006; Golden and Picci, 2008; Kemmerling and Stephan, 2015). Drawing on this literature, we argue that the county-level distribution of SIF is a function of the electoral considerations of the executive branch of government at the national level.

To begin with, electoral institutions shape politicians' incentives and ability to use EU funds to please voters. Politicians have an interest in using SIF for electoral purposes, expecting citizens to overestimate the reward of the projects, as the costs of EU funding are diffuse (Schraff, 2014). Given that SIF allocations shape individual attitudes even among people with relatively low levels of political awareness (Chalmers and Dellmuth, 2015, p. 401), the assumption that politicians will expect citizens to link the receipt of EU funds to the 
incumbent government is warranted. ${ }^{4}$ In using EU funds for electoral purposes, politicians face a trade-off between their short-term re-election goal and their long-term goal to retrieve all available EU funds in order to receive a similar or larger amount of SIF in the following budgetary period (Dellmuth, 2011). However, politics works in the short run (Lowi, 1964). We expect politicians to care more about their re-election chances since they cannot be certain that they will be in office during the ensuing budgetary period and be able to reap the benefits from greater EU funding.

\section{National Executives' Incentives to Use EU Funds to Buy Votes}

The distribution of SIF is not decided by domestic parliaments but by executive authorities at the regional and national level (cf. Bachtler and Mendez, 2007). In line with a burgeoning literature about electoral institutions and heads of governments' vote-seeking behavior (e.g., Bertelli and Grose, 2009; Berry et al., 2010; Kriner and Reeves, 2015), we expect that politicians in the executive branch of national government have incentives to influence the county-level allocation of SIF.

National governments have more bargaining power in the allocation process than the Commission since they are able to reduce the Commission's competencies through reforms (cf. Pollack, 2003). Although the Commission is responsible for the correct implementation of the EU budget, its means and incentives to interfere with domestic funding strategies are fairly limited, as oversight procedures and sanctions are costly (Blom-Hansen, 2005; Dellmuth and Stoffel, 2012). However, the Commission uses soft law instruments, such as guidelines and recommendations, to influence SIF allocations (Bachtler and Mendez, 2007). Hence, even if the Commission may encroach on a national governments' leeway in

\footnotetext{
${ }^{4}$ This premise is further corroborated by a series of recent Flash Eurobarometer polls. These polls show that more than a third of EU citizens were aware of EU funding in their region during 2007-2013. In addition, the polls suggest that investing SIF may increase rewards for politicians in the future, as awareness increases over time in more heavily funded regions (FEB, 2008: 5; FEB 2010: 8; FEB 2013: 7).
} 
implementing SIF, governments retain substantial room for maneuver in making distributive decisions at the county level (De Rynck and McAleavey, 2001). Moreover, national governments' bargaining power is greater than regional governments' bargaining power if national governments co-finance the greater part of the SIF compared to regional governments. This is the case in unitary states, where regional governments lack a strong tax base (OECD, 2013). Without own tax revenues, regional governments have a weak bargaining position in the implementation of the SIF, as they depend on the willingness of national governments to co-finance projects (Chalmers, 2013). These considerations translate into the following hypothesis:

H1: In unitary states, national executives will distribute the SIF across counties with the aim to enhance their re-election chances.

\section{Partisan Harmony and National Executives’ Distributive Calculus}

National executives' vote-buying behavior may be constrained by partisan alignment with regional chief executives. Generally speaking, co-partisanship and distributive politics are related due to the vertical integration of politicians in party networks (Riker, 1964). Regional chief executives that are affiliated with one of the parties in national government may depend on national executives as the latter have influence over partisan careers (Campbell, 1986). From the perspective of national executives, it is uncertain that voters will reward them for their spending efforts if the subnational chief executive has another partisan affiliation, as voters rarely understand differences between different levels of government. Cooperation with co-partisans in regional government reduces such uncertainty because politicians at both levels can coordinate on credit-claiming initiatives (Arceneaux, 2006). In line with this reasoning, there is evidence that regional executives that are politically aligned with national 
executives receive larger amounts of EU funding (Bouvet and Dall'erba, 2010; Bodenstein and Kemmerling, 2011; Chalmers, 2013).

The relationship between partisan alignment and distributive politics has been shown in the context of the alignment of national and regional levels (Grossman, 1994) or national and local levels (Solé-Ollé and Sorribas-Navarro, 2008). In the context of the SIF, the partisan harmony hypothesis may only be meaningfully applied to regional governments at the NUTS 1 or NUTS 2 level that actually manage SIF, as they have the capacity to influence the county-level distribution of SIF in ways that affect national governments' preferences. We expect national governments to gain leverage vis-à-vis regional governments during times of partisan harmony, as partisan harmony may facilitate policy cooperation and provide national politicians with the ability to discipline their regional co-partisans when allocating SIF across counties. We expect this logic to hold in the context of both popularly elected regional chief executives and centrally appointed civil servants. Bureaucrats may benefit from targeted redistribution in an indirect fashion since the reappointment of national politicians increases their chances of staying in office. ${ }^{5}$ We hypothesize that:

H2: The political targeting of the SIF will be more pronounced in times of partisan harmony between regional and national executives.

\section{Electoral Institutions and National Executives’ Distributive Calculus}

Electoral rules differ with regard to the extent to which they incentivize using public capital for electoral politics. A prominent distinction in the ongoing debate concerns the differences in incentives in MAV and PRV systems (Kemmerling and Stephan, 2015). There is evidence for distributive politics both under MAV (e.g., Grossman, 1994; Berry et al., 2010) and PRV (e.g., Lancaster, 1986; Golden and Picci, 2008), however, there are important differences.

\footnotetext{
${ }^{5}$ For a discussion of the incentives of targeted redistribution among elected and appointed officials in the context of American politics, see Enikolopov (2014).
} 
Politicians in MAV systems are commonly portrayed as having strong incentives to use public capital to win district races. By contrast, PRV may constrain politicians' incentives to engage in distributive politics, as personal resources are weaker, voter loyalties are directed to parties rather than individuals, and the electoral fate of individual politicians are less clear (e.g., Persson and Tabellini, 2002). Rather than encouraging vote-buying among individual politicians, PRV yields incentives for party cabinets to improve their party's re-election chances through the allocation of public capital, as their individual fortunes rest on the victory of the party as a whole (e.g., Lancaster, 1986; Golden and Picci, 2008).

Taking cues from this literature, we expect targeted spending of the SIF to be more pronounced under MAV. In contrast to their executive counterparts in MAV systems, national chief executives in PRV systems should have fewer incentives to provide disproportionate amounts of funding in specific counties, as they cannot claim singular responsibility for the allocation of EU funding to counties. We would expect that:

H3: The political targeting of the SIF will be more pronounced under MAV than under PRV.

Taken together, the hypotheses predict that electoral institutions provide national executives with incentives to use SIF to buy votes (H1), whereby the effects of vote-seeking behavior on county-level SIF allocations should be stronger in times of partisan alignment between regional and national government $(\mathrm{H} 2)$, and under MAV when compared to PRV (H3). It is an empirical question how national executives will distribute EU funds among counties, that is, if they will target electoral strongholds or rather voters of the opposition parties (cf. Dahlberg and Johansson, 2002; McGillivray, 2005, pp. 3, 17-21; Berry et al., 2010; Kemmerling and Stephan, 2015). In the following empirical analysis, we examine both possibilities. 


\section{Research Design}

County-level allocations at the NUTS 3 level in Italy and France are managed at the level of regions at the NUTS 2 level, which corresponds to the 19 regioni in Italy and the 22 régions in France. In France, NUTS 2 regions administer more than 60 percent of the EU funds available to France. From 2007-2013, regional authorities at the NUTS 2 level managed 8.9 billion Euro of the available 14.3 billion Euro, whereas national authorities managed about 4.5 billion Euro. In Italy, regional authorities at the NUTS 2 level are responsible for the implementation of about 20.1 of 28.8 billion Euro available to Italy, that is, almost 70 percent, whereas the national government managed only 8.3 billion Euro (European Communities, 2007).

We create two dependent variables to measure SIF allocations at the county level: ERDF and ESF expenditure per capita. For this purpose, we collected expenditure data from the lists of final project beneficiaries provided by the French Agence de Services et de Paiement $^{6}$ and the Italian Department for Development and Economic Cohesion. ${ }^{7}$ These lists provide information on the yearly amount of EU funding allocated to single projects from the years 2007-2013. We aggregate this spending data across all years to the county level, that is, to the level of the 96 French départments and 106 Italian provinces. $^{8}$

To examine whether counties with relatively many core voters receive larger amounts of EU funds, we create a variable measuring the vote share of the government in Italy and the president in France in the last national election prior to the funding period in $2007 .{ }^{9}$ In Italy, the center-left alliance L'Unione led by Romano Prodi was elected in 2006. In France,

\footnotetext{
${ }^{6}$ Available at: «http://cartobenef.asp-public.fr/cartobenef/».

${ }^{7}$ Available at: «http://www.opencoesione.gov.it/».

${ }^{8}$ See Figure A1 in the online appendix for a map of ERDF and ESF allocations in Italy and France. Table A1 presents summary statistics for ERDF and ESF spending.

${ }^{9}$ In France, we use data from the presidential election from 2002. In Italy, data are derived from the general parliamentary election from 2006.
} 
Jacques Chirac was elected president in $2002 .{ }^{10}$ Chirac can be considered the dominant figure in the executive since his own party UMP held a majority of seats in parliament. We explore whether counties receive larger amounts of funding the more county residents support national government, measured as L'Unione vote share in Italy and second round vote share for Chirac in France. Moreover, we measure partisan harmony through a dichotomous measure that is 1 if the regional chief executive managing the county-level allocation of SIF is affiliated with one of the parties forming the national government (coalition) (cf. Chalmers, 2013). Last, we capture a country's electoral system using a country dummy that is 1 for MAV systems in a pooled analysis of county-level SIF allocations (cf. Kemmerling and Stephan 2015).

Next, we include a range of economic and geographic control variables, measured for the year 2006, as the subnational investment plans were negotiated during that year (cf. Dellmuth and Stoffel, 2012). ${ }^{11}$ As the EU's own funding criteria are rather imprecise, we conducted semi-structured interviews with five EU policy-makers from different EU institutions in 2008 to help identifying appropriate control variables. The interviews yield anecdotal evidence on the political and economic motivations and aims behind the county and regional-level allocation of European funds. We conducted interviews in four EU bodies with politicians and civil servants that have several years of expertise in the field of EU cohesion policy. ${ }^{12}$ The interview partners suggested that the $2007-2013$ period was characterized by the

\footnotetext{
${ }^{10}$ The French presidential election of 2002 was characterized by unprecedented developments. In the second round, Chirac competed against Jean-Marie Le Pen, a candidate of the right-wing party Front National. As a consequence, Chirac achieved an all-time high in support of 82 percent, with voters coming from most parts of the political spectrum. Nonetheless, distributive politics can be expected to operate even in the context of this particular election.

${ }^{11}$ The exception is GDP per capita at the NUTS 3 level in Italy, which is coded for 2010 and is not available for any year before 2010. See Table A2 in the online appendix for an overview of the correlations between the economic and geographical variables.

${ }^{12}$ Interviewees include two representatives from the top- and middle-management in the Commission's Directorate General for Regional Policy (interview A and B), one representative of the Committee of the Regions (interview C), one from the European Court of Auditors with experience in auditing EU structural policy (interview D), and one member of the European Parliament who was a member of the budget committee at that time (interview E).
} 
EU's attempts to boost competitiveness in the EU by investing SIF in employment, research and development, and growth. Two of the interviewees stressed that while the EU's aim was to influence funding strategies in line with the 'Europe 2020' strategy, in practice, the shift to investment in both competitiveness and fiscal equity was rather slow across different member states. Indeed, SIF were often spent on rather unconnected projects that served a different purpose (interviewees D and E). Taken together, the interviews suggest that proxies for the 'Europe 2020' goals of competitiveness and equity are appropriate measures to hold EU policy aims during the period 2007-2013 constant.

To control for the goal to enhance competitiveness, we derive measures for GDP per capita and unemployment rates from Eurostat for NUTS 3 counties. We also include GDP per capita and unemployment rates for NUTS 2 regions, as the economic performance of regions may have implications for the distribution of SIF across counties. To capture the EU's goal to promote fiscal equity in the EU, we include log area size at the county level since larger areas are typically less industrialized and dependent on agriculture, making them more vulnerable to structural changes. Hence, we expect larger areas to receive higher levels of funding. Finally, we include the $\log$ population density as a measure of the degree of urbanization in a county. Relatively urbanized counties may experience higher levels of crime and social tensions, which is why population density should increase transfer levels. These two geographical controls are complementary. If two counties are of equal size, the more populated county should receive more funds. If two counties are equally populated, the larger county should receive more funds (cf. Dellmuth and Stoffel, 2012).

To select the appropriate regression model, we assume that the expenditure data follow a gamma process. To begin with, observed spending levels are always positive. Consequently, the gamma distribution only generates positive-valued data, whereas the normal distribution can lead to negative predicted values of spending. Moreover, like expenditure data in general, 
our data at hand are right-skewed even after a log transformation. There are many counties receiving very low levels of aggregate funding, whereas higher levels of funding are more dispersed. The gamma framework allows for such an asymmetric distribution. ${ }^{13}$

As the managing authorities for the SIF are located at the NUTS 2 level, we control for unobserved variation at the NUTS 2 level that may affect SIF allocations within NUTS 2 regions in a multilevel setting. To this end, we include random intercepts $\eta_{i}$ at the regional level, which allow for varying mean spending levels across space. Our estimation strategy is implemented in a mixed gamma generalized linear model using a log-link:

$$
\begin{gathered}
Y_{i j} \sim \operatorname{Gamma}\left(y_{i j} \mid \lambda_{i j}, \alpha\right), \text { where } y_{i j}, \lambda_{i j}, \alpha>0 \\
\lambda_{i j}=\frac{1}{x_{i j}+\eta_{i}} \\
\eta_{i} \sim \mathcal{N}(0, \psi),
\end{gathered}
$$

where $\alpha$ denotes the scale parameter of the gamma distribution, which is constant across regions and counties. Levels of spending $Y_{i j}$ are indexed by region $i$ and individual county $j$. Since the gamma regression, in the way in which it is implemented here, uses a log-link, changes in the independent variables affect the log of the dependent variable in expectation, that is, $\log \left(\mathbb{E}\left[Y_{i j}\right]\right)=\mathbf{x}_{i j} \boldsymbol{\beta}+\eta_{i}$

\section{Empirical Analysis}

The empirical analysis proceeds in two steps. First, we present separate analyses for Italy and France to investigate $\mathrm{H} 1$ and $\mathrm{H} 2$. Second, we pool the data for Italy and France to explore $\mathrm{H} 3$. Moreover, we analyze ERDF and ESF spending separately. As spending goals and investment

\footnotetext{
${ }^{13}$ In Figure A2 in the online appendix, we show that the gamma distribution fits our data.
} 
volumes under the auspices of these two funds differ, financial transfers through these funds will be susceptible to political manipulation to different degrees.

We begin by examining $\mathrm{H} 1$ in the context of county-level allocations in Italy. The results in Table 1 strongly endorse $\mathrm{H} 1$. With regard to ERDF funding, model 1 presents a baseline model excluding government re-election incentives. These are introduced in model 2 using the governing coalition's vote share. The coefficient of vote share is statistically significant and in the expected direction. We find spending levels to be higher where L'Unione had greater electoral support in the election of 2006. Moving from a province with particular low support for the left wing parties (10th percentile) to a stronghold province (90th percentile) - a difference of about twenty percentage points in vote shares - raises ERDF funding by more than half, all else equal (see Figure 1). Consider the example of the cities of Verona and Florence, which are very similar according to our control measures. L'Unione faired particularly badly in Verona, receiving only 35 percent of all votes. By contrast, the coalition received strong support in Florence, achieving the third-best national-level election result with 67 percent. Verona received 83 million Euro, whereas Florence was allocated 160 million Euro.

\section{$* * *$ Table 1 about here $* * *$ \\ *** Figure 1 about here ***}

We analyze the determinants of the distribution of ESF in model 4 . The results for the control variables are similar to the results in the context of the ERDF, with regions receiving larger amounts of funding the higher their GDP per capita, the more they depend on agriculture, and the more they are urbanized. Nonetheless, the results from the ESF support $\mathrm{H} 1$, as the electoral calculus of the governing coalition has an impact on county receipts 
(model 5). The coefficient of vote share is positive and significant. Moving from weak to stronghold counties increases the amount of ESF funding by roughly 20 percent.

The distributive politics literature provides several leads to understand these results. Cox and McCubbins (1986) have argued in their 'core voter model' that in the presence of two parties competing in an election, risk-averse parties distribute targetable goods to their core voters and not to other groups such as swing voters. This model rests on the assumption that politicians invest in voters that promise the highest rate of return, that is, voters that have consistently supported the candidate and which the candidate does not want to lose. As this model deals with benefits to groups of voters and not to geographical areas, previous authors have not directly applied but taken cues from core voter theory to formulate and test arguments about the political targeting of jurisdictions (e.g., Dahlberg and Johansson, 2002; Berry et al., 2010; Dellmuth and Stoffel, 2012; Schraff, 2014). In line with previous applications of the core voter model, we find that national executives channel more SIF to counties with relatively many core voters.

To explore H2, we interpret model 3 in Table 1 . The results from model 3 do not provide evidence for a conditioning effect of partisan harmony. In model 3 , neither the dummy for the composition of regional governments $(1=L$ 'Unione $)$ nor the interaction with this dummy variable and L'Unione's national vote share are statistically significant. Findings for the ESF are similar. Thus, while partisan congruence between regional and national executives may matter for SIF allocations across regions (Bouvet and Dall'erba, 2010; Chalmers, 2013), our results suggest that partisan harmony does not affect the county-level allocation of SIF.

Next, we turn to the determinants of ERDF funding in France. The baseline model 6 in Table 2 demonstrates that GDP per capita at both the regional and county level has explanatory power. Interestingly, the positive coefficient of GDP per capita at the county 
level indicates that spending is concentrated in more prosperous counties, similarly to our results from Italy. Furthermore, spending levels are smaller in densely populated, that is, urbanized counties, all else equal.

\section{$* * *$ Table 2 about here $* * *$}

We test $\mathrm{H} 1$ in France through model 7. France uses a majority-runoff system both for presidential and parliamentary elections. To measure vote-seeking behavior, we use the second round vote share in both instances, as this measure determines who is elected president and the composition of parliament, respectively. The effect for president Chirac's vote share in 2002 is significant and positive, thereby corroborating H1. Moving from the 10th to the 90th percentile in vote share is a step of about 13 percentage points. This step more than doubles ERDF spending in a département (by a factor of 2.4), indicating that the French administration enjoys much leeway in allocating funds to the electoral benefit of the president (see Figure 2). To illustrate this finding, consider the following example. The counties Hautes-Pyrénées and Tarn-et-Garonne are both located in the Midi-Pyrénées and are very similar with regard to the economic and geographical covariates. Yet Hautes-Pyrénées received 34.4 million in funding, that is, almost twice the amount of Tarn-et-Garonne (17.8 million) as the national government's vote share is only about nine percentage points larger in Haute-Pyrénées than in Tarn-et-Garonne. Again, these findings are in accordance with the core voter model.

\footnotetext{
$* * *$ Figure 2 about here ***
} 
Testing H1 in the context of ESF spending in Table 2, we find a substantial effect of Chirac's vote share on ESF allocations. Increasing vote share by 13 percentage points raises the amount of funds allocated to a NUTS 3 unit by 75 percent. In contrast to the second-round presidential vote share, neither the first-round presidential nor parliamentary vote share of the presidential party UMP are related to the distribution of funds (both ERDF and ESF). The first-round presidential vote share encompasses only a very limited group of a party's voters, which is too small for winning an absolute majority. By contrast, the second round vote share indicates the final potential for electoral support. That the parliamentary vote share does not explain spending behavior reflects the strong powers with which the semi-presidential system equips the president, even though the government is formally appointed by the legislature. Since the presidential party UMP held a majority of the seats in the legislature, thus enabling unified government, Jacques Chirac was the dominant figure in French politics.

Testing $\mathrm{H} 2$ in France, the findings from model 8 suggest that the regional variation in party composition does not affect funding. Instead, some of the control variables have the expected effects: log area size and log population density. Furthermore, GDP per capita both at the regional and county level is a strong and significant predictor of ESF transfer payments in France. Taken together, the results suggest that economic criteria influence ERDF and ESF spending in France more than ERDF and ESF spending in Italy.

Next, we explore H3, which would lead us to expect stronger effects of vote share in France than in Italy. We pool the data for both countries, add a country-specific dummy variable to tap differences in the electoral system, and interact this dichotomous measure with vote share (cf. Kemmerling and Stephan 2015). Since the vote share variable differs between Italy and France in terms of mean value and standard deviation, we standardize the vote share variables to make them comparable across countries. Figure 3 depicts the estimated difference 
in spending between Italy and France with 95 percent confidence intervals. ${ }^{14}$ Negative values indicate that a county received less spending in France than in Italy, whereas positive values indicate the opposite, all else equal. The difference is negative for low levels of vote share and positive for high levels, indicating that the distributive effect of vote share is stronger in France. These results provide empirical support for H3. To be sure, the country dummy is a crude but in the context of this study inevitable proxy for differences in electoral systems. This dummy variable may capture country-specific differences other than electoral system differences as well. However, in the context of our regression analysis we control for the theoretically relevant political, economic, and institutional factors, which is why we interpret this finding as supportive evidence for H3. Moreover, the results for H3 tie in with extensive research on the linkages between electoral systems, vote-buying, and public expenditure (for an overview, see Kemmerling and Stephan, 2015), which increases our confidence that our interpretation is warranted.

$* * *$ Figure 3 about here $* * *$

Finally, we test a potentially alternative explanation pertaining to regional autonomy. H1 may play out differently in the context of varying levels of regional autonomy under unitary government (cf. Chalmers, 2013). To examine this possibility, we replicated models 2 and 7 by including an interaction term between vote share and the regional authority index (RAI) by Hooghe et al. (2008) at the NUTS 2 level where the SIF are managed. In both Italy and France, this interaction term was insignificant (see Table A4 in the online appendix), indicating that SIF allocations across Italian and French regions are not affected by differences in regional authority. It is important to note that in a pooled cross-country

\footnotetext{
${ }^{14}$ Figure 3 is based on the estimations reported in Table A3 in the online appendix.
} 
analysis, all French NUTS 2 regions would have considerably lower RAI levels than their Italian counterparts. Therefore, irrespective of the within-country variation in the RAI, in a joint analysis of both countries the effect of the RAI and the effect of a country dummy would be almost identical. ${ }^{15}$ We used a country dummy to examine electoral system differences in spending behavior (H3). Since the within-country analysis did not yield evidence for a conditioning effect of regional authority, the cross-country analysis of an effect of electoral systems on spending in Figure 3 should not be interpreted as evidence for an effect of regional authority either, but as evidence for an effect of electoral systems.

We discuss these findings against the backdrop of previous research in the concluding section.

\section{Conclusion}

As more and more financial resources are redistributed through the EU budget, the political determinants of SIF allocations have attracted increasing scholarly attention over the past two decades. The comparative county-level analysis of EU spending in Italy and France advanced here contributes to expanding our understanding of a largely unexplored issue, namely, the effects of electoral institutions on the county-level distribution of SIF. The central finding is that national executives channel disproportionate amounts of EU funds to counties with relatively many core voters, whereby executives' vote-buying behavior is more pronounced under majority voting than under PRV. These results are robust even if we control for a range of economic and geographic factors. While the evidence for an effect of economic and geographic factors on SIF allocations is mixed, needs-related factors appear to matter more for SIF allocations at the county level in France than in Italy. Finally, while previous literature has shown that NUTS 1 and 2 regions whose executives are politically aligned with national

\footnotetext{
15 The point biserial correlation is 0.995 .
} 
executives receive larger amounts of EU funding (e.g., Bouvet and Dall'erba, 2010; Chalmers, 2013), we do not find that partisan congruence matters for county-level allocations.

All told, this article's findings suggest three fruitful avenues for future research. To begin with, our finding that electoral institutions provide politicians with incentives to use EU funds for distributive awards at the county level warrants further research in a variety of electoral systems. A first useful step would be to analyze the effects of electoral institutions on actual SIF payments in a larger number of EU member states. As our findings hold in unitary states with varying electoral systems and regional authority, they should travel to other unitary states in the EU, that is, to all EU member states except for Austria, Belgium, Germany, Spain, and the UK. However, data from other time periods and from comparisons between federal and unitary states might render different verdicts.

Second, our results complement previous research on institutional capacity and the domestic implementation of the EU budget. Scholars of both Europeanization and territorial politics have shown how institutional capacity shapes the performance of regions (Milio, 2007) and member states (Tosun, 2013) in absorbing SIF. Absorption capacity, in turn, affects the amount of funding earmarked for regions in ensuing funding periods (Dellmuth, 2011). Scholars need to pay more attention to linking theories of electoral politics and institutional capacity in explaining variation in the distribution and the effectiveness of the SIF. Several questions remain unanswered. For example, what is the effect of institutional capacity on the political targeting of the SIF in counties? Does institutional capacity influence the degree to which politicians have leeway in distributing SIF, and if so with what consequences for the political and distributional outcomes of EU cohesion policy? These are a few of the questions we leave for future research.

Third and finally, our results raise questions about the effectiveness of the SIF in promoting 'Europe 2020' goals. The traditional interpretation in political economy research is 
to regret political influences on resource distribution from an effectiveness perspective (cf. Kemmerling and Bodenstein, 2006). If electoral considerations distort a needs-based allocation of EU funds, then this may undermine the funds' effectiveness. At the same time, electoral politics is a natural component of the democratic process. From this starting point, future research should engage ways to examine the conditions under which electoral considerations and institutional capacity reduce the effectiveness of EU funds.

\section{References}

Arceneaux, K. (2006) 'The Federal Face of Voting: Are Elected Officials Held Accountable for the Functions Relevant to their Office?'. Political Psychology, Vol. 27, No. 5, pp. $731-54$.

Bachtler, J. and Mendez, C. (2007) 'Who Governs EU Cohesion Policy? Deconstructing the Reforms of the Structural Funds'. Journal of Common Market Studies, Vol. 45, No. 3, pp. 535-64.

Berry, C. R., Burden, B. C., and Howell, W. G. (2010) 'The President and the Distribution of Federal Spending'. American Political Science Review, Vol. 104, No. 4, pp. 783-99.

Bertelli, A. M. and Grose, C. R. (2009) 'Secretaries of Pork? A New Theory of Distributive Public Policy’. Journal of Politics, Vol. 71, No.3, pp. 926-45.

Blom-Hansen, J. (2005) 'Principals, Agents, and the Implementation of EU Cohesion Policy'. Journal of European Public Policy, Vol. 12, No. 4, pp. 624-48.

Bodenstein, T. and Kemmerling, A. (2011) 'Ripples in a Rising Tide: Why Some EU Regions Receive More Structural Funds than Others'. European Integration online Papers (EIoP). Vol. 16, Article 1 http://eiop.or.at/eiop/texte/2012-001a.htm. 
Bouvet, F. and Dall'erba, S. (2010) 'European Regional Structural Funds: How Large is the Influence of Politics on the Allocation Process?'. Journal of Common Market Studies, Vol. 48, No. 3, pp. 501-28.

Cadot, O., Röller, L.-H., and Stephan, A. (2006) 'Contribution to Productivity or Pork-Barrel? The Two Faces of Infrastructure Investment'. Journal of Public Economics, Vol. 90, No. 6-7, pp. 1133-53.

Campbell, J. E. (1986) 'Presidential Coattails and Midterm Losses in State Legislative Elections. American Political Science Review, Vol. 80, No. 1, pp. 45-63.

Chalmers, A. W. (2013) 'Regional Authority, Transnational Lobbying and the Allocation of Structural Funds in the European Union'. Journal of Common Market Studies, Vol. 51, No. 5, pp. 815-31.

Chalmers, A. W. and Dellmuth, L. M. (2015) 'Fiscal Redistribution and Public Support for European Integration'. European Union Politics, Vol. 16, No. 3, pp. 386-407.

Cox, G. W. and McCubbins, M. D. (1986) 'Electoral Politics as a Redistributive Game'. Journal of Politics, Vol. 48, No. 2, pp. 370-389.

Dahlberg, M. and Johansson, E. (2002) 'On the Vote-Purchasing Behavior of Incumbent Governments'. American Political Science Review, Vol. 96, No. 1, pp. 27-40.

De Rynck, S. and McAleavey, P. (2001) 'The Cohesion Deficit in Structural Fund Policy'. Journal of European Public Policy, Vol. 8, No. 4, pp. 541-57.

Dellmuth, L. M. (2011) 'The Cash Divide. The Allocation of European Union Regional Grants'. Journal of European Public Policy, Vol. 18, No. 7, pp. 1016-33.

Dellmuth, L. M. and Stoffel, M. F. (2012) 'Distributive Politics and Intergovernmental Transfers: The Local Allocation of European Union Structural Funds'. European Union Politics, Vol. 13, No. 3, pp. 413-33. 
Enikolopov, R. (2014) 'Politicians, Bureaucrats and Targeted Redistribution'. Journal of Public Economics, Vol. 120, pp. 74-83.

European Commission (2010) 553 final: Regional Policy Contributing to Smart Growth in Europe 2020. SEC(2010) 1183.

European Commission (2015) Managing authorities. Available at: «http://ec.europa.eu/regional_policy/en/atlas/managing-authorities/».

European Communities (2007) Cohesion Policy 2007-2013. National Strategic Reference Frameworks (Luxembourg: European Commission).

Golden, M. A. and Picci, L. (2008) 'Pork-Barrel Politics in Postwar Italy, 1953-94'. American Journal of Political Science, Vol. 52, No. 2, pp. 268-289.

Grossman, P. J. (1994) ‘A Political Theory of Intergovernmental grants’. Public Choice, Vol. 78, No. 3-4, pp. 295-303.

Hooghe, L., Marks, G., and Schakel, A. H. (2008) 'Operationalizing Regional authority: A Coding Scheme for 42 Countries, 1950-2006'. Regional and Federal Studies, Vol. 18, No. 2-3, pp. 123-42.

Kemmerling, A. and Bodenstein, T. (2006) 'Partisan Politics in Regional Redistribution. Do Parties Affect the Distribution of EU Structural Funds Across regions?'. European Union Politics, Vol. 7, No. 3, pp. 373-92.

Kemmerling, A. and Stephan, A. (2015) 'Comparative Political Economy of Regional Transport Infrastructure Investment in Europe'. Journal of Comparative Economics, Vol. 43, No. 1, pp. 227-239.

Kriner, d. L. and Reeves, A. (2015) The Particularistic President: Executive Branch Politics and Political Inequality (Cambridge: Cambridge University Press).

Lancaster, T. D. (1986) 'Electoral Structures and Pork Barrel Politics'. International Political Science Review, Vol. 7, No. 1, pp. 67-81. 
Lowi, T. J. (1964) 'American Business, Public Policy, Case-Studies and Political Theory'. World Politics, Vol. 16, No. 4, pp. 677-715.

McGillivray, F. (2005) Privileging Industry: The Comparative Politics of Trade and Industrial Policy (Princeton: Princeton University Press).

Milio, S. (2007) 'Can Administrative Capacity Explain Differences in Regional Performances? Evidence from Structural Funds Implementation in Southern Italy'. Regional Studies, Vol. 41, No. 4, pp. 429-42.

Organization for Economic Co-operation and Development (OECD) (2013) Revenue Statistics 2013. Paris: OECD.

Persson, T. and Tabellini, G. (2002) Political Economics. Explaining Economic Policy (Cambridge, MA: MIT Press).

Pollack, M. A. (2003) The Engines of European integration: Delegation, Agency and Agenda Setting in the EU (Oxford: Oxford University Press).

Riker, W. H. (1964) Federalism: Origin, Operation, Significance (Boston: Little Brown).

Schraff, D. (2014) 'Buying Turnout or Rewarding Loyalists? Electoral Mobilization and EU Structural Funding in the German Länder'. European Union Politics, Vol. 15, No. 2, pp. $277-88$.

Solé-Ollé, A. and Sorribas-Navarro, P. (2008) 'The Effects of Partisan Alignment on the Allocation of Intergovernmental Transfers: Differences-in-Differences Estimates for Spain. Journal of Public Economics 92: 2302-2319.

Tosun, J. (2013) 'Absorption of Regional Funds: A Comparative Analysis'. Journal of Common Market Studies, Vol. 52, No. 2, pp. 371-87. 


\section{Supporting Information}

Additional supporting information may be found in the online version of this article at the publisher's web-site, including the following tables and figures:

Appendix Table A1: Summary statistics

Appendix Table A2: Correlation matrix

Appendix Table A3: Joint regression analysis for ERDF spending per capita in Italy and France

Appendix Table A4: ERDF spending per capita with regional autonomy Appendix Figure A1: Gamma distribution of SIF across counties 
Table 1: Gamma multilevel regression results for Italy

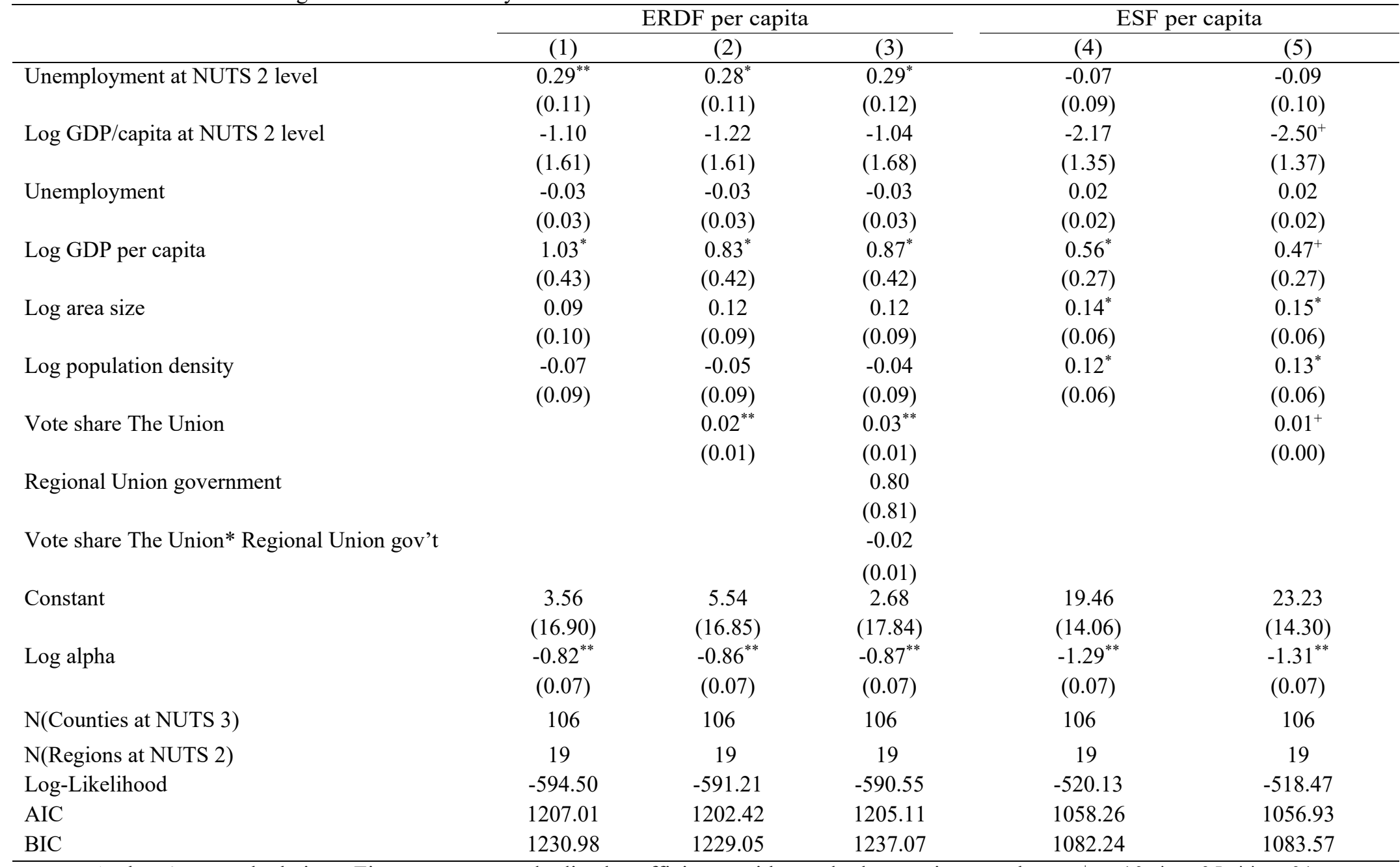

Notes: Authors' own calculations. Figures are unstandardized coefficients, with standard errors in parentheses; ${ }^{+} \mathrm{p}<.10,{ }^{*} \mathrm{p}<.05,{ }^{*} \mathrm{p}<.01$. 
Table 2: Gamma multilevel regression results for France

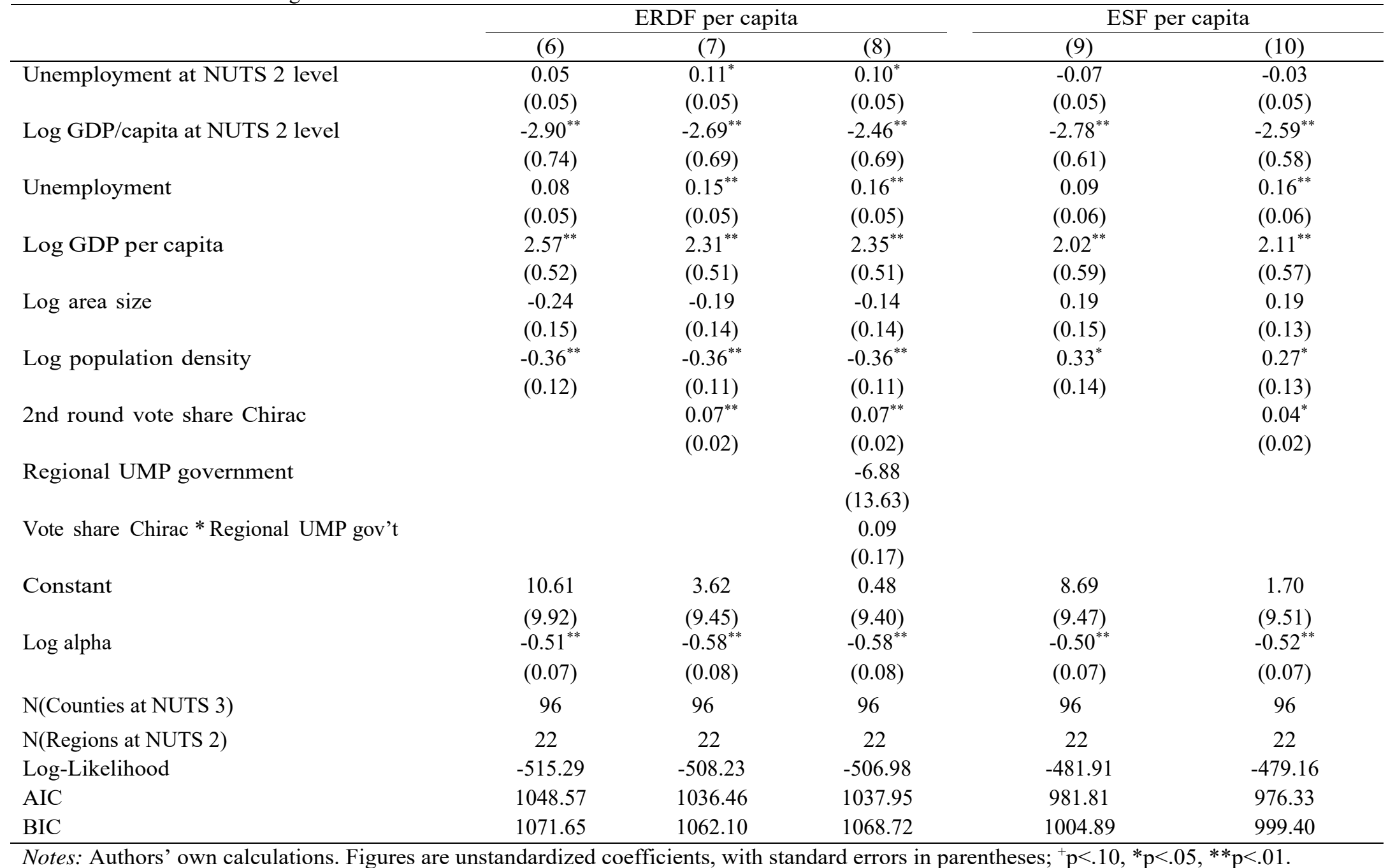


Figure 1: Predicted effect of vote share on ERDF spending per capita in Italy

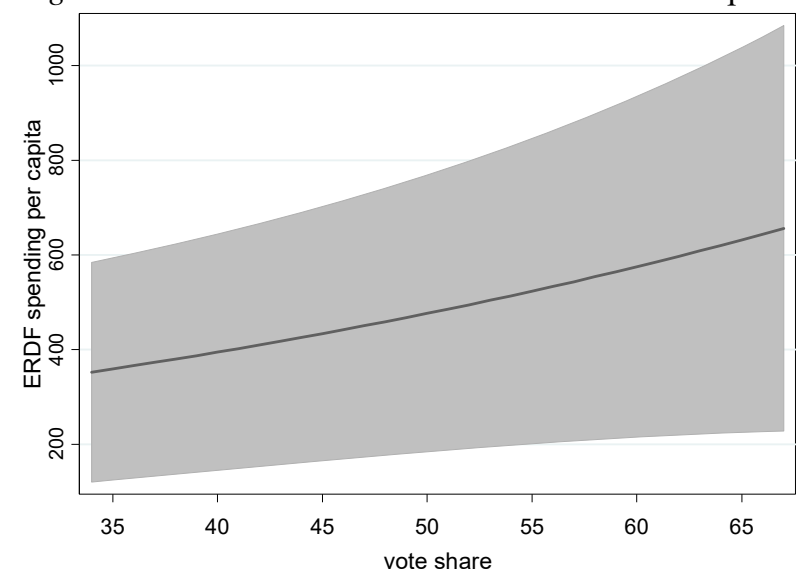

Notes: Authors' own calculations. Left-hand panel depicts results for Italy, right-hand panel for France.

Figure 2: Predicted effect of vote share on ERDF spending per capita in France

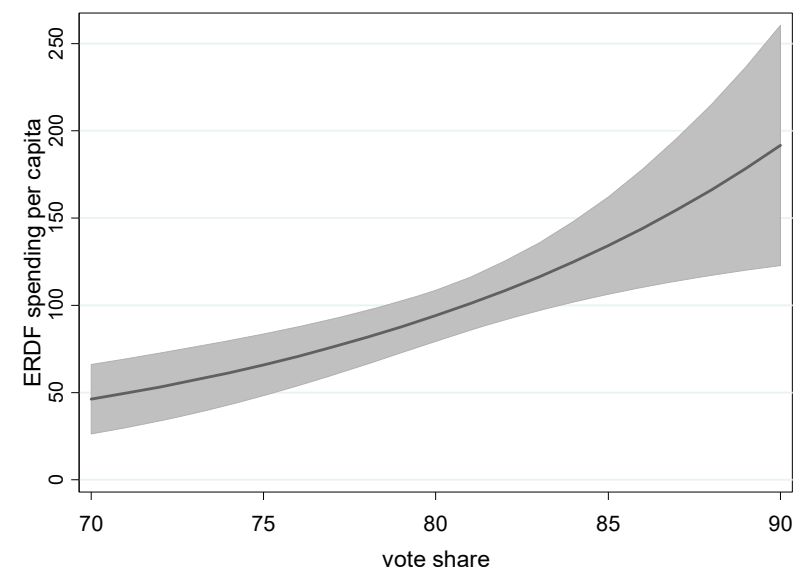

Notes: Authors' own calculations.

Figure 3: Predicted difference in ERDF spending per capita under MAV and PRV

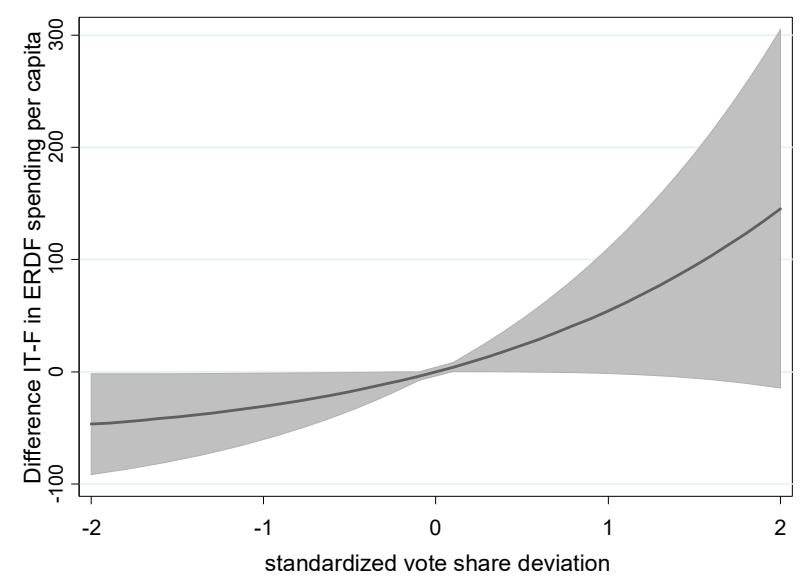

Notes: Authors' own calculations. 


\section{Online appendix}

Table A1: Summary statistics

\begin{tabular}{lccccc}
\hline & Min. & Median & Mean & Max. & Std. dev. \\
\hline Italy ESF & 1.3 & 29.0 & 70.0 & 414.6 & 94.9 \\
Italy ERDF & 2.6 & 37.1 & 172.0 & 2531.0 & 368.9 \\
France ESF & 1.5 & 22.4 & 65.8 & 586.4 & 106.0 \\
France ERDF & 7.1 & 31.0 & 66.1 & 667.5 & 96.9 \\
\hline
\end{tabular}

Notes: Figures are in million Euro.

Table A2: Correlation matrix

\begin{tabular}{|c|c|c|c|c|c|c|}
\hline & 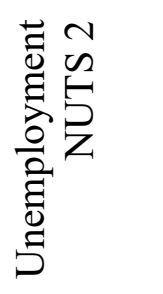 & 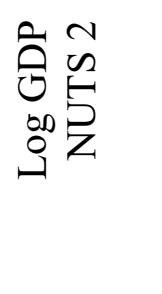 & 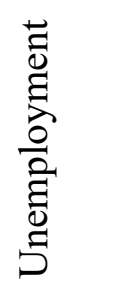 & $\begin{array}{l}0 \\
0 \\
0 \\
0 \\
0\end{array}$ & 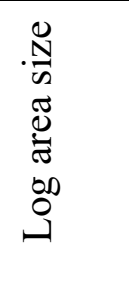 & 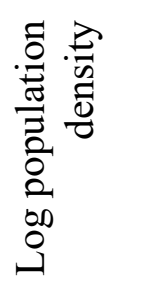 \\
\hline \multicolumn{7}{|l|}{ Italy } \\
\hline Unemployment NUTS 2 & 1.00 & & & & & \\
\hline Log GDP NUTS 2 & -0.95 & 1.00 & & & & \\
\hline Unemployment & 0.93 & -0.88 & 1.00 & & & \\
\hline Log GDP & -0.87 & 0.86 & -0.83 & 1.00 & & \\
\hline Log area size & 0.19 & -0.17 & 0.14 & -0.08 & 1.00 & \\
\hline Log population density & -0.18 & 0.20 & -0.14 & 0.32 & -.045 & 1.00 \\
\hline \multicolumn{7}{|l|}{ France } \\
\hline Unemployment NUTS 2 & 1.00 & & & & & \\
\hline Log GDP NUTS 2 & -0.07 & 1.00 & & & & \\
\hline Unemployment & 0.53 & -0.16 & 1.00 & & & \\
\hline Log GDP & -0.03 & 0.60 & -0.14 & 1.00 & & \\
\hline Log area size & -0.07 & -0.70 & -0.10 & -0.65 & 1.00 & \\
\hline Log population density & 0.13 & 0.73 & 0.18 & 0.76 & -0.81 & 1.00 \\
\hline
\end{tabular}


Table A3: Joint regression analysis for ERDF spending per capita in Italy and France

\begin{tabular}{lc}
\hline Unemployment at NUTS 2 & $0.12^{*}$ \\
Log GDP/capita at NUTS 2 & $(0.05)$ \\
& $-3.36^{* *}$ \\
Unemployment & $(0.77)$ \\
& 0.01 \\
Log GDP per capita & $(0.03)$ \\
& $1.28^{* *}$ \\
Log area size & $(0.32)$ \\
& -0.07 \\
Log population density & $(0.08)$ \\
& -0.06 \\
Standardized gov't voteshare & $(0.08)$ \\
& $0.16^{*}$ \\
Standardized gov't voteshare ${ }^{*}$ MAV & $(0.07)$ \\
& $0.25^{*}$ \\
Constant & $(0.12)$ \\
& $25.56^{* *}$ \\
Log alpha & $(8.13)$ \\
& $-0.69^{* *}$ \\
N(Counties at NUTS 3) & $(0.05)$ \\
N(Regions at NUTS 2) & 202 \\
Log-Likelihood & 41 \\
AIC & -1120.43 \\
\hline BIC & 2262.87 \\
\hline Notes: Standard errors in parentheses: ${ }^{+} p<0.10,{ }^{*} p<0.05,^{* *} p<0.01$
\end{tabular}


Table A4: ERDF spending per capita with regional autonomy

\begin{tabular}{lcc}
\hline & Italy & France \\
\hline Unemployment at NUTS 2 & $0.27^{*}$ & $0.08^{+}$ \\
Log GDP/capita at NUTS 2 & $(0.11)$ & $(0.05)$ \\
& -1.60 & $-2.33^{* *}$ \\
Unemployment & $(1.66)$ & $(0.67)$ \\
& -0.03 & $0.16^{* *}$ \\
Log GDP per capita & $(0.03)$ & $(0.05)$ \\
& $0.83^{*}$ & $2.31^{* *}$ \\
Log area size & $(0.42)$ & $(0.50)$ \\
& 0.09 & -0.09 \\
Log population density & $(0.10)$ & $(0.14)$ \\
& -0.05 & $-0.33^{* *}$ \\
Standardized gov’t voteshare & $(0.09)$ & $(0.11)$ \\
& 1.77 & 0.34 \\
RAI NUTS 2 & $(2.57)$ & $(4.00)$ \\
& -0.09 & -0.00 \\
Standardized gov't voteshare * RAI NUTS2 & $(0.14)$ & $(0.40)$ \\
& -0.32 & 0.39 \\
Constant & $(0.37)$ & $(0.27)$ \\
& 16.37 & 1.13 \\
Log alpha & $(18.83)$ & $(9.84)$ \\
& $-0.86^{* *}$ & $-0.58^{* *}$ \\
N(Counties at NUTS 3) & $(0.07)$ & $(0.08)$ \\
N(Regions at NUTS 2) & 106 & 96 \\
Log-Likelihood & 19 & 22 \\
AIC & -590.63 & -505.63 \\
BIC & 1205.26 & 1035.26 \\
\hline
\end{tabular}

Notes: Standard errors in parentheses: ${ }^{+} p<0.10,{ }^{*} p<0.05,{ }^{* *} p<0.01$ 
Figure A1: Map of the distribution of SIF across counties
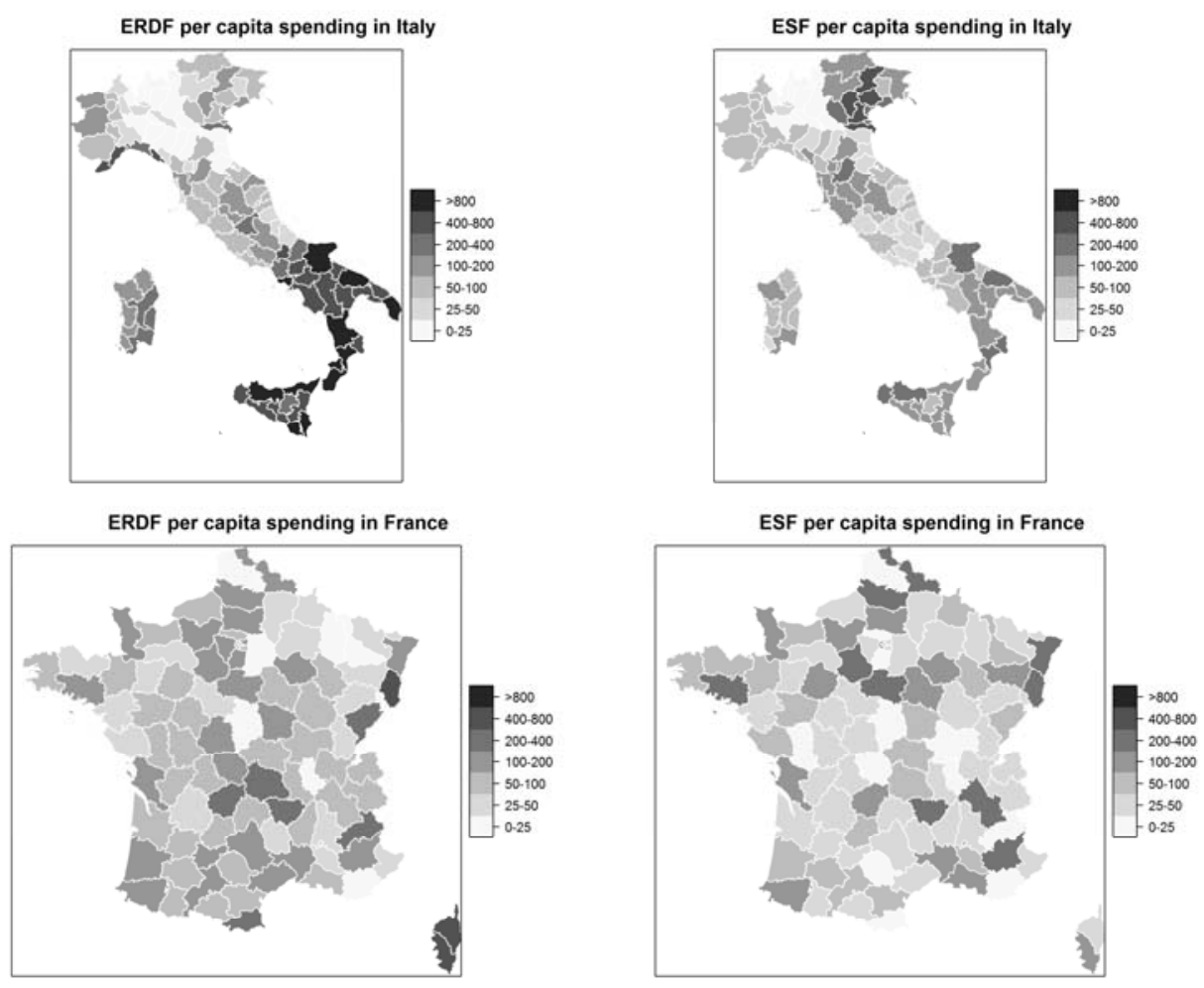

Notes: Authors' own calculations using data from Eurostat and national authorities. 
Figure A2: Gamma distribution of SIF across counties
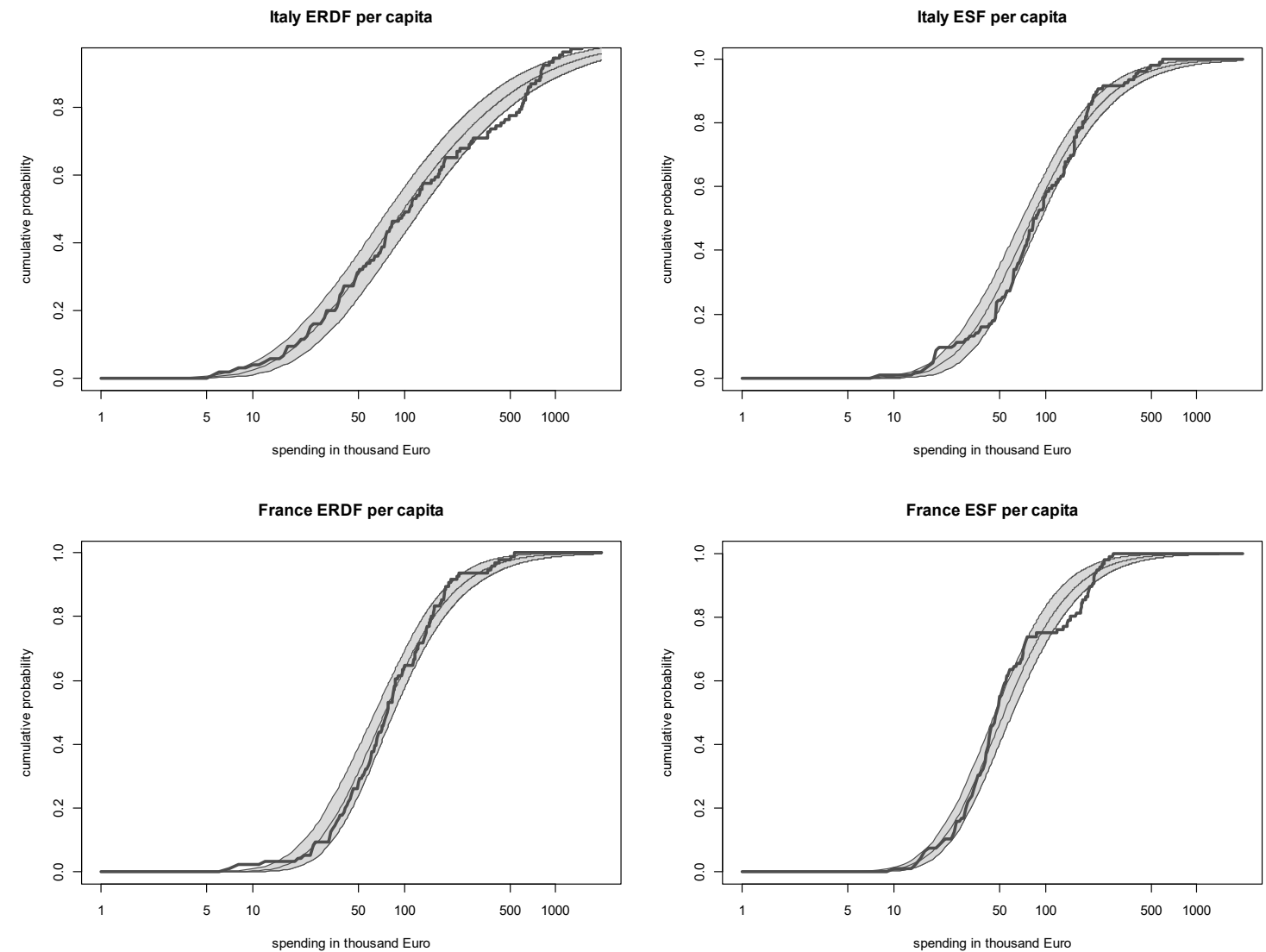

Notes: Authors' own calculations using data from national authorities. Bold gray lines represent the empirical cumulative distribution function for ERDF and ESF spending levels in Italy and France. The light-gray shaded areas give 95 percent bootstrapped confidence bands of estimated gamma distributions. Figure A1 clearly shows that the observed data fall within the estimated gamma confidence bands. 